\title{
Influence of Crop Establishment and Irrigation Methods on Nutrient Uptake and Post Harvest Available Nutrients of Bajra Napier Hybrid Grass CO (BN) 5
}

\author{
S. V. Varshini" and C. Jayanthi \\ Department of Agronomy, Agricultural College and Research Institute, Tamil Nadu \\ Agricultural University, Coimbatore, India \\ *Corresponding author
}

\begin{tabular}{|l|}
\hline Ke y w o r d s \\
$\begin{array}{l}\text { Crop Establishment, } \\
\text { Nutrients of Bajra }\end{array}$ \\
\hline Article Info \\
\hline $\begin{array}{l}\text { Accepted: } \\
12 \text { November } 2020 \\
\text { Available Online: } \\
10 \text { December } 2020\end{array}$ \\
\hline
\end{tabular}

\section{A B S T R A C T}

A field experiment to assess influence of crop establishment and irrigation methods on nutrient uptake, post harvest available nutrients of bajra napier hybrid grass $\mathrm{CO}(\mathrm{BN}) 5$ was conducted during 2018-2019 at the Eastern block farm of the Department of Agronomy, Tamil Nadu Agricultural University - Coimbatore, Tamil Nadu. The field was laid out in a strip plot design with three replications. Irrigation methods were imposed in main plot viz., $\mathbf{M}_{1}$ : Surface irrigation, $\mathbf{M}_{2}$ : Surface drip irrigation, $\mathbf{M}_{3}$ : Subsurface drip irrigation, $\mathrm{M}_{4}$ : Micro sprinkler irrigation and crop establishment methods in sub plot viz., $\mathrm{S}_{1}$ : Vertical planting of setts with sett treatment, $S_{2}$ : Horizontal planting of setts with sett treatment, $S_{3}$ : Vertical planting of setts without sett treatment, $S_{4}$ : Horizontal planting of setts without sett treatment, $S_{5}$ : Vertical planting of two budded setts. Sett treatment adopted for the study was 12 hours water soaking followed by 24 hours incubation. The treatments $S_{1}$ to $S_{4}$ were adapted with single budded setts. The results on nutrient uptake showed significant difference on irrigation methods and crop establishment methods. Among irrigation methods significantly higher nitrogen $(157.4 \mathrm{~kg} / \mathrm{ha})$, phosphorous $(29.8$ $\mathrm{kg} / \mathrm{ha})$ and potassium $(88.2 \mathrm{~kg} / \mathrm{ha})$ uptake was recorded with subsurface drip irrigation $\left(\mathrm{M}_{3}\right)$. In crop establishment methods, horizontal planting of setts with sett treatment registered higher nitrogen $(155.9 \mathrm{~kg} / \mathrm{ha})$, phosphorus $(29.1 \mathrm{~kg} / \mathrm{ha})$ and potassium $(92.2$ $\mathrm{kg} / \mathrm{ha}$ ) uptake. But, interaction effect between irrigation methods and crop establishment methods showed non-significant difference on nutrient uptake. In post harvest soil available nutrients, irrigation methods and crop establishment methods showed significant difference. Whereas interaction effect showed non-significant difference on post harvest available nutrients. With regarded to irrigation methods, significantly higher soil available nitrogen (172. $3 \mathrm{~kg} / \mathrm{ha})$, soil available phosphorus $(22.2 \mathrm{~kg} / \mathrm{ha})$ and soil available potassium (591.5 $\mathrm{kg} / \mathrm{ha})$ was recorded with surface irrigation $\left(\mathrm{M}_{1}\right)$. Among crop establishment methods, vertical planting of setts without sett treatment $\left(\mathrm{S}_{3}\right)$ registered higher soil available nitrogen $(172.1 \mathrm{~kg} / \mathrm{ha})$, soil available phosphorus $(23.3 \mathrm{~kg} / \mathrm{ha})$ and soil available potassium $(604.8 \mathrm{~kg} / \mathrm{ha})$. With this, it can be concluded that for irrigation method, subsurface drip irrigation $\left(\mathrm{M}_{3}\right)$, and for crop establishment methods, horizontal planting of setts with sett treatment $\left(\mathrm{S}_{2}\right)$ are the recommended practices for achieving better quality and nutrient uptake from bajra napier hybrid grass. 


\section{Introduction}

Livestock is considered to be the integral part of Indian agriculture. It also holds a vital position in the Indian economy. Livestock contribute about $8.8 \%$ employment for India. Livestock or related business accounts for about $4.5 \%$ of our national GDP and about $25.6 \%$ of our agricultural GDP. India has three major sources for fodder viz., crop residues, cultivated fodder and fodder available from forests, permanent pastures and grazing lands. In India fodder are grown in different seasons and its distribution are surplus in some areas but deficit in some other areas. Minimum fodder cultivation with minimal inputs leads to a huge gap between fodder requirement and production.

Bajra Napier (BN) is one of the important perennial fodder crop with high yielding potential among different grass fodders cultivated. Generally its vegetative propagation is through stem cuttings (setts) (Singh et al., 2011). But, multiplication and sale of planting material have a major constraints, such as, high transportation cost due to high volume, damage to the standing crop from where rooted slips are taken out, involvement of high labour cost, etc (Vijay et al., 2018).

The major limitation of bajra napier is requirement of large amount of planting material. This large planting material requirement poses a huge problem in transport, handling and storage of sett material and undergoes rapid deterioration thus reducing the viability of buds and subsequently their sprouting. One alternative to reduce the mass and improve the quality of sett is reduce sett size with treatment (Jain et al., 2010).

Water is the most vital input in agriculture and has made a significant contribution in providing stability of food grain production. India has an irrigation potential of about $139.89 \mathrm{~m}$ ha of which $108.3 \mathrm{~m}$ ha (i.e. about 77 per cent) has already been utilised. The per capita storage capacity in India is only about $207 \mathrm{~m}^{3}$ as compared to $1111 \mathrm{~m}^{3}$ in China. Out of the total water supply, the share of irrigation at present is about 80 per cent. This is likely to go down to 73 per cent by 2025 (Hans, 2016).

The major limiting factor on the expansion of irrigated agriculture throughout the world is the lack of water. Water demand is increasing due to fast population growth rates, improvement in living standards, improvement in industry and municipality, and global warming (Kirnak, 2006). Micro irrigation is convenient and effective means of supplying water directly to soil and nearer to the plant without much loss of water resulting in higher water productivity.

For bajra napier grass implementing such irrigation practices will improve the water use efficiency of the fodder there by increase the water conservation. This may attract more number of farmers to invest on fodder cultivation, since water is considered to be the pronounced barrier for the farmers to go far bajra napier fodder crop cultivation requiring. Keeping this in view this study was conducted to optimize the best irrigation methods and crop establishment methods for good establishment and to improve the nutrient uptake of bajra napier hybrid grass.

\section{Materials and Methods}

A field experiment to study the Influence of crop establishment and irrigation methods on nutrient uptake, post harvest available nutrients on bajra napier hybrid grass $\mathrm{CO}$ (BN) 5 was conducted during September, 2018 in Field No. 75 at the Eastern block of Department of Agronomy, Tamil Nadu 
Agricultural University - Coimbatore. The experimental field was on a soil with sandy clay loam texture. Climatic conditions were with a rainfall of about $693 \mathrm{~mm}$, maximum minimum temperatures of $32^{\circ} \mathrm{C}$ and $23^{\circ} \mathrm{C}$ respectively and morning evening relative humidity 84 and $52 \%$ respectively. The chemical composition of the soil comprised of $\mathrm{pH} 8.49$, EC $0.55 \mathrm{dS} / \mathrm{m}$, organic carbon $0.57 \%$, available nitrogen $204 \mathrm{~kg} / \mathrm{ha}$, available phosphorus $33 \mathrm{~kg} / \mathrm{ha}$ and available potassium $769 \mathrm{~kg} / \mathrm{ha}$.

The field was laid out in a strip plot design with three replications. Irrigation methods were imposed in main plot viz., $\mathrm{M}_{1}$ : Surface irrigation, $\mathrm{M}_{2}$ : Surface drip irrigation, $\mathrm{M}_{3}$ : Subsurface drip irrigation, $\mathrm{M}_{4}$ : Micro sprinkler irrigation and crop establishment methods in sub plot viz., $\mathrm{S}_{1}$ : Vertical planting of setts with sett treatment, $S_{2}$ : Horizontal planting of setts with sett treatment, $S_{3}$ : Vertical planting of setts without sett treatment, $\mathrm{S}_{4}$ : Horizontal planting of setts without sett treatment, $\mathrm{S}_{5}$ : Vertical planting of two budded setts. Sett treatment adopted for the study was 12 hours water soaking followed by 24 hours incubation. The treatments $S_{1}$ to $S_{4}$ were adapted with single budded setts.

For main plot, Scheduling of irrigation for surface irrigation was done based on IW/CPE ratio 0.80 i.e., cumulative pan evaporation value when arrived at $62.5 \mathrm{~mm}$ throughout the crop period. Daily pan evaporation rate was recorded from the standard USWB Class A Open pan evaporimeter installed in the field. Irrigation was given to the depth of $5 \mathrm{~cm}$. For micro irrigation systems, the experimental field was irrigated upto saturation through surface, subsurface drip and micro sprinkler irrigation system after planting. Surface, subsurface drip and micro sprinkler irrigation were scheduled once in three days based on $100 \%$ pan evaporation.
The quantity of water applied in surface, subsurface drip and micro sprinkler irrigation was calculated by using the following formula suggested by Bhoi and More (2005).

Volume of irrigation $(\mathrm{V})=3$ days $\mathrm{CPE} \times \mathrm{Kp}$ $\times \mathrm{Kc} \times \mathrm{Wp} \times \mathrm{A}-\mathrm{ER}$

Where,

$\mathrm{V} \quad$ - Volume of water required in litres

CPE - Cumulative pan evaporation for three days (mm)

$\mathrm{Kp} \quad$ - $\quad$ Pan factor (0.75)

$\mathrm{Kc} \quad$ - $\quad$ Crop factors

A $\quad$ - Area $\left(\mathrm{m}^{2}\right)$

Wp - Wetted percentage (surface \& subsurface drip $-80 \%$ and microsprinkler$100 \%$ )

ER - $\quad$ Effective rainfall $(\mathrm{mm})$

Time of application of surface, subsurface drip and micro sprinkler system to deliver the required volume of water was computed based on the formula given below.

$$
\text { Time of application }=\frac{\text { Volume of water required (l) }}{\text { Emitter/micro sprinkler discharge bed and plot (l) } \mathrm{x} \text { No. }}
$$

The surface, subsurface drip and micro sprinkler irrigation plots received irrigation once in three days with discharge rate of $4 \mathrm{lph}$ and $102 \mathrm{lph}$ respectively with $95 \%$ distribution uniformity efficiency.

The field was thoroughly ploughed and applied with recommended dose of NPK 75:50:40 $\mathrm{kg} / \mathrm{ha}$ at basal, subsequently 75 $\mathrm{kg} / \mathrm{ha}$ of nitrogen was applied at 30 DAP. For sub plot, the single budded setts were treated as per treatment schedule and planted vertically and horizontally in their respective plots and two budded setts was planted 
vertically without sett treatment with a spacing of $60 \mathrm{~cm} X 50 \mathrm{~cm}$. In order to analyse nutrient uptake of the crop, five plants were selected randomly from each net plot area from each treatment and were tagged. The mean values obtained from seven cuts were used for the analysis.

For measuring available nutrients, soil samples from the experimental plots were drawn from a depth of $0-30 \mathrm{~cm}$ before planting and after each harvest. Samples collected were air dried and ground to pass through $2 \mathrm{~mm}$ sieve and used for chemical analysis of $\mathrm{N}, \mathrm{P}$ and $\mathrm{K}$. The mean values were arrived and expressed as $\mathrm{kg} / \mathrm{ha}$.

To obtain the total nutrient uptake, plants samples which were collected for estimating dry matter production at harvest were oven dried at $65 \pm 5^{\circ} \mathrm{C}$ for nutrient analysis. The dried samples were ground in a Willey mill to pass through $40 \mathrm{~mm}$ mesh sieve and composite sample (leaf and stem) was used for estimating the content of total nitrogen, phosphorus and potassium as per the standard procedure presented in Table 1. Total uptake of $\mathrm{N}, \mathrm{P}$ and $(\mathrm{kg} / \mathrm{ha})$ were calculated based on the nutrient content in plant multiplying with dry matter yield.

The total uptake of $\mathrm{N}, \mathrm{P}$ and $\mathrm{K}$ by crop was computed as follows:

\section{Nutrient content $(\%)$ x total dry matter ( $\mathrm{kg} / \mathrm{ha})$ \\ Total uptake of nutrient $(\mathrm{kg} / \mathrm{ha})=$}

The statistical analysis of the data of nutrient uptake and post harvest available nutrients was done using the statistical method of strip plot design. Wherever the results were significant, the critical difference (CD) at $5 \%$ level of significance was worked out as given by Gomez and Gomez (1984).

\section{Results and Discussion}

\section{Nitrogen uptake (kg/ha)}

The data pertaining to nitrogen uptake under irrigation methods and crop establishment methods are presented in Figure 1. A profound significant difference was found with irrigation methods and crop establishment methods for bajra napier hybrid grass $\mathrm{CO}(\mathrm{BN}) 5$ on nitrogen uptake and interaction effect was found to be nonsignificant for nitrogen uptake. Substantially, the highest uptake of nitrogen was registered with subsurface drip irrigation $\left(\mathrm{M}_{3}\right)$ which recorded $157.4 \mathrm{~kg} / \mathrm{ha}$ and this was followed by surface drip irrigation $\left(\mathrm{M}_{2}\right)$ with 142.3 $\mathrm{kg} / \mathrm{ha}$ of nitrogen uptake. This was superior to micro sprinkler irrigation $\left(\mathrm{M}_{4}\right)$ which recorded $121.1 \mathrm{~kg} / \mathrm{ha}$ of nitrogen uptake. Relatively lower nitrogen uptake of 114.6 $\mathrm{kg} / \mathrm{ha}$ was observed with surface irrigation $\left(\mathrm{M}_{1}\right)$.

Among the crop establishment methods, horizontal planting with sett treatment $\left(S_{2}\right)$ recorded higher uptake of nitrogen of 155.9 $\mathrm{kg} / \mathrm{ha}$. This was comparable with vertical planting of two budded setts $\left(\mathrm{S}_{5}\right)$ which recorded $152.1 \mathrm{~kg} / \mathrm{ha}$ of nitrogen uptake. However, significantly lower uptake of 112.6 $\mathrm{kg} / \mathrm{ha}$ nitrogen was observed with vertical planting of setts without sett treatment $\left(\mathrm{S}_{3}\right)$.

\section{Phosphorus uptake (kg/ha)}

The data related to phosphorus uptake by irrigation methods and crop establishment methods are furnished in Figure 1. Phosphorus uptake of bajra napier hybrid grass $\mathrm{CO}(\mathrm{BN}) 5$ under irrigated condition registered the greater impact by irrigation methods and crop establishment methods. Whereas, interaction effect between irrigation methods and crop establishment methods showed non-significant difference on 
phosphorus uptake. Significantly, the highest phosphorus uptake of $29.8 \mathrm{~kg} / \mathrm{ha}$ was observed with subsurface drip irrigation $\left(\mathrm{M}_{3}\right)$. It was followed by surface drip irrigation $\left(\mathrm{M}_{2}\right)$ which recorded phosphorus uptake of 26.7 $\mathrm{kg} / \mathrm{ha}$. But, surface irrigation $\left(\mathrm{M}_{1}\right)$ recorded lower phosphorus uptake of $19.5 \mathrm{~kg} / \mathrm{ha}$.

Horizontal planting of setts with sett treatment $\left(\mathrm{S}_{2}\right)$ had evidently recorded higher phosphorus uptake of $29.1 \mathrm{~kg} / \mathrm{ha}$. It was at par with vertical planting of two budded setts $\left(\mathrm{S}_{5}\right)$ which recorded phosphorus uptake of 27.7 $\mathrm{kg} / \mathrm{ha}$ and followed by vertical planting of setts with sett treatment $\left(\mathrm{S}_{1}\right)$ having 24.6 $\mathrm{kg} / \mathrm{ha}$ of phosphorus uptake. Noticeably, lower phosphorus uptake of $19.6 \mathrm{~kg} / \mathrm{ha}$ was observed with vertical planting of setts without sett treatment $\left(\mathrm{S}_{3}\right)$

\section{Potassium uptake (kg/ha)}

The data on potassium uptake of bajra napier hybrid grass $\mathrm{CO}(\mathrm{BN}) 5$ under different irrigation methods and crop establishment methods are presented in Figure 1. Significant variation was observed on potassium uptake as influenced by irrigation methods and crop establishment methods. But, interaction effect between irrigation methods and crop establishment methods had no significant variation on potassium uptake. Potassium uptake was significantly superior under subsurface drip irrigation $\left(\mathrm{M}_{3}\right)$ which recorded the highest value of $88.2 \mathrm{~kg} / \mathrm{ha}$. This was followed by surface drip irrigation $\left(\mathrm{M}_{2}\right)$ with a potassium uptake of $81.8 \mathrm{~kg} / \mathrm{ha}$. Whereas, apparently lower potassium uptake of $71.4 \mathrm{~kg} / \mathrm{ha}$ was observed with surface irrigation $\left(\mathrm{M}_{1}\right)$.

Among the crop establishment methods, horizontal planting of setts with sett treatment $\left(\mathrm{S}_{2}\right)$ registered higher potassium uptake of $92.2 \mathrm{~kg} / \mathrm{ha}$. This was at par with vertical planting of two budded setts $\left(\mathrm{S}_{5}\right)$ which recorded $89.0 \mathrm{~kg} / \mathrm{ha}$ of potassium uptake. Whereas, vertical planting of setts without sett treatment $\left(\mathrm{S}_{3}\right)$ had recorded lower potassium uptake of $65.6 \mathrm{~kg} / \mathrm{ha}$.

Influence of crop establishment and irrigation methods on post harvest soil available nutrients

\section{Soil available nitrogen (kg/ha)}

The data pertaining to soil available nitrogen of bajra napier hybrid grass $\mathrm{CO}(\mathrm{BN}) 5$ under irrigation methods and crop establishment methods are presented in Table 2. During the course of investigation, soil available nitrogen differed significantly by irrigation methods and crop establishment methods. However, interaction effect had no significant difference on soil available nitrogen. With regarded to irrigation methods, higher soil available nitrogen of $172.3 \mathrm{~kg} / \mathrm{ha}$ was observed with surface irrigation $\left(\mathrm{M}_{1}\right)$. It was followed by micro sprinkler irrigation $\left(\mathrm{M}_{4}\right)$ which recorded $158.6 \mathrm{~kg} / \mathrm{ha}$ of soil available nitrogen. Whereas, notably lower soil available nitrogen of $145.0 \mathrm{~kg} / \mathrm{ha}$ was registered with subsurface drip irrigation $\left(\mathrm{M}_{3}\right)$.

Vertical planting of setts without sett treatment $\left(\mathrm{S}_{3}\right)$ recorded higher soil available nitrogen of $172.1 \mathrm{~kg} / \mathrm{ha}$ and this was at par with horizontal planting of setts without sett treatment $\left(\mathrm{S}_{4}\right)$ which registered $165.5 \mathrm{~kg} / \mathrm{ha}$ of soil available nitrogen. Significantly lower soil available nitrogen of $143.6 \mathrm{~kg} / \mathrm{ha}$ was observed with horizontal planting of setts with sett treatment $\left(\mathrm{S}_{2}\right)$.

\section{Soil available phosphorus (kg/ha)}

The data on soil available phosphorus of bajra napier hybrid grass $\mathrm{CO}$ (BN) 5 by irrigation methods and crop establishment methods are furnished in Table 3. Irrigation methods and 
crop establishment methods had marked influence on soil available phosphorus. Whereas, interaction effect of irrigation methods and crop establishment methods showed non-significant difference on soil available phosphorus. Higher soil available phosphorus of $22.2 \mathrm{~kg} / \mathrm{ha}$ was observed with surface irrigation $\left(\mathrm{M}_{1}\right)$. It was followed by micro sprinkler irrigation $\left(\mathrm{M}_{4}\right)$ which recorded $20.7 \mathrm{~kg} / \mathrm{ha}$ of soil available phosphorus. However, notably lower soil available phosphorus of $17.6 \mathrm{~kg} / \mathrm{ha}$ was observed with subsurface drip irrigation $\left(\mathrm{M}_{3}\right)$.

The result revealed that vertical planting of setts without sett treatment $\left(S_{3}\right)$ recorded higher soil available phosphorus of $23.3 \mathrm{~kg} / \mathrm{ha}$ and it was at par with horizontal planting of setts without sett treatment $\left(\mathrm{S}_{4}\right)$ which recorded $22.4 \mathrm{~kg} / \mathrm{ha}$ of soil available phosphorus. The lower soil available phosphorus of $16.4 \mathrm{~kg} / \mathrm{ha}$ was observed with horizontal planting of setts with sett treatment $\left(\mathrm{S}_{2}\right)$. It was on par with vertical planting of two budded setts $\left(\mathrm{S}_{5}\right)$ with a soil available phosphorus of $17.2 \mathrm{~kg} / \mathrm{ha}$.

\section{Soil available potassium (kg/ha)}

The data related to soil available phosphorus of bajra napier hybrid grass $\mathrm{CO}(\mathrm{BN}) 5$ under irrigation methods and crop establishment methods are presented in Table 4. Soil available potassium was significantly influenced by irrigation methods and crop establishment methods individually but for the interaction affect of irrigation methods and crop establishment methods it was found to be non-significant. With respect to irrigation methods, increased soil available potassium of $591.5 \mathrm{~kg} / \mathrm{ha}$ was observed with surface irrigation $\left(\mathrm{M}_{1}\right)$ and this was followed by micro sprinkler irrigation $\left(\mathrm{M}_{4}\right)$ which recorded $555.5 \mathrm{~kg} / \mathrm{ha}$ of soil available potassium. Significantly, decreased soil available potassium of $499.3 \mathrm{~kg} / \mathrm{ha}$ was observed with subsurface drip irrigation $\left(\mathrm{M}_{3}\right)$.

Table.1 Details of analytical methods employed for plant analysis

\begin{tabular}{|l|c|c|}
\hline Name of the analysis & Methodology & Procedure followed \\
\hline Nitrogen & Micro Kjeldahl method & (Humphries, 1956) \\
\hline Phosphorus & Triple acid digestion method & (Jackson, 1973) \\
\hline Potassium & Triple acid digestion method & (Jackson, 1973) \\
\hline
\end{tabular}

Table.2 Influence of method of establishment and irrigation methods on post harvest soil available nitrogen $(\mathrm{kg} / \mathrm{ha})$ of bajra napier hybrid grass

\begin{tabular}{|c|c|c|c|c|c|c|}
\hline Treatments & $\mathbf{S}_{\mathbf{1}}$ & $\mathbf{S}_{\mathbf{2}}$ & $\mathbf{S}_{\mathbf{3}}$ & $\mathbf{S}_{\mathbf{4}}$ & $\mathbf{S}_{\mathbf{5}}$ & Mean \\
\hline $\mathbf{M}_{\mathbf{1}}$ & 173.0 & 155.8 & 187.7 & 181.2 & 163.9 & $\mathbf{1 7 2 . 3}$ \\
\hline $\mathbf{M}_{\mathbf{2}}$ & 150.5 & 140.3 & 169.5 & 157.9 & 144.0 & $\mathbf{1 5 2 . 4}$ \\
\hline $\mathbf{M}_{\mathbf{3}}$ & 140.9 & 137.3 & 154.8 & 152.6 & 139.5 & $\mathbf{1 4 5 . 0}$ \\
\hline $\mathbf{M}_{\mathbf{4}}$ & 155.8 & 141.0 & 176.3 & 170.3 & 149.4 & $\mathbf{1 5 8 . 6}$ \\
\hline Mean & $\mathbf{1 5 5 . 0}$ & $\mathbf{1 4 3 . 6}$ & $\mathbf{1 7 2 . 1}$ & $\mathbf{1 6 5 . 5}$ & $\mathbf{1 4 9 . 2}$ & \\
\hline & $\mathbf{M}$ & $\mathbf{S}$ & $\mathbf{M}$ at $\mathbf{S}$ & $\mathbf{S}$ at $\mathbf{M}$ & & \\
\hline SEd & $\mathbf{3 . 8}$ & $\mathbf{4 . 9}$ & $\mathbf{9 . 5}$ & $\mathbf{9 . 8}$ & & \\
\hline $\mathbf{C D}(\mathbf{P}=\mathbf{0 . 0 5})$ & $\mathbf{9 . 3}$ & $\mathbf{9 . 9}$ & $\mathbf{N S}$ & $\mathbf{N S}$ & & \\
\hline
\end{tabular}


Table.3 Influence of method of establishment and irrigation methods on post harvest soil available phosphorus $(\mathrm{kg} / \mathrm{ha})$ of bajra napier hybrid grass

\begin{tabular}{|c|c|c|c|c|c|c|}
\hline Treatments & $\mathbf{S}_{\mathbf{1}}$ & $\mathbf{S}_{\mathbf{2}}$ & $\mathbf{S}_{\mathbf{3}}$ & $\mathbf{S}_{\mathbf{4}}$ & $\mathbf{S}_{\mathbf{5}}$ & Mean \\
\hline $\mathbf{M}_{\mathbf{1}}$ & 22.9 & 17.4 & 26.1 & 26.1 & 18.5 & $\mathbf{2 2 . 2}$ \\
\hline $\mathbf{M}_{\mathbf{2}}$ & 19.9 & 16.4 & 21.8 & 21.7 & 17.1 & $\mathbf{1 9 . 4}$ \\
\hline $\mathbf{M}_{\mathbf{3}}$ & 18.0 & 15.0 & 20.5 & 19.2 & 15.4 & $\mathbf{1 7 . 6}$ \\
\hline $\mathbf{M}_{\mathbf{4}}$ & 21.6 & 16.8 & 24.8 & 22.4 & 17.7 & $\mathbf{2 0 . 7}$ \\
\hline Mean & $\mathbf{2 0 . 6}$ & $\mathbf{1 6 . 4}$ & $\mathbf{2 3 . 3}$ & $\mathbf{2 2 . 4}$ & $\mathbf{1 7 . 2}$ & \\
\hline & $\mathbf{M}$ & $\mathbf{S}$ & $\mathbf{M} \mathbf{a t} \mathbf{S}$ & $\mathbf{S}$ at M & & \\
\hline SEd & $\mathbf{0 . 5}$ & $\mathbf{0 . 6}$ & $\mathbf{1 . 2}$ & $\mathbf{1 . 1}$ & & \\
\hline $\mathbf{C D}(\mathbf{P}=\mathbf{0 . 0 5})$ & $\mathbf{1 . 3}$ & $\mathbf{1 . 2}$ & $\mathbf{N S}$ & $\mathbf{N S}$ & \\
\hline
\end{tabular}

Table.4 Influence of method of establishment and irrigation methods on post harvest soil available potassium $(\mathrm{kg} / \mathrm{ha})$ of bajra napier hybrid grass

\begin{tabular}{|c|c|c|c|c|c|c|}
\hline Treatments & $\mathbf{S}_{\mathbf{1}}$ & $\mathbf{S}_{\mathbf{2}}$ & $\mathbf{S}_{\mathbf{3}}$ & $\mathbf{S}_{\mathbf{4}}$ & $\mathbf{S}_{\mathbf{5}}$ & Mean \\
\hline $\mathbf{M}_{\mathbf{1}}$ & 607.3 & 516.6 & 645.8 & 622.8 & 565.0 & $\mathbf{5 9 1 . 5}$ \\
\hline $\mathbf{M}_{\mathbf{2}}$ & 563.0 & 490.5 & 592.7 & 574.6 & 528.0 & $\mathbf{5 4 9 . 7}$ \\
\hline $\mathbf{M}_{\mathbf{3}}$ & 487.2 & 433.9 & 575.3 & 528.7 & 471.2 & $\mathbf{4 9 9 . 3}$ \\
\hline $\mathbf{M}_{\mathbf{4}}$ & 565.9 & 495.9 & 605.2 & 579.7 & 530.7 & $\mathbf{5 5 5 . 5}$ \\
\hline Mean & $\mathbf{5 5 5 . 8}$ & $\mathbf{4 8 4 . 2}$ & $\mathbf{6 0 4 . 8}$ & $\mathbf{5 7 6 . 4}$ & $\mathbf{5 2 3 . 7}$ & \\
\hline & $\mathbf{M}$ & $\mathbf{S}$ & $\mathbf{M} \mathbf{a t} \mathbf{S}$ & $\mathbf{S} \mathbf{a t} \mathbf{M}$ & & \\
\hline $\mathbf{S E d}$ & $\mathbf{1 0 . 2}$ & $\mathbf{1 5 . 1}$ & $\mathbf{2 8 . 9}$ & $\mathbf{3 0 . 2}$ & & \\
\hline $\mathbf{C D}(\mathbf{P}=\mathbf{0 . 0 5})$ & $\mathbf{2 4 . 9}$ & $\mathbf{3 0 . 8}$ & $\mathbf{N S}$ & $\mathbf{N S}$ & & \\
\hline
\end{tabular}

Fig.1 Influence of crop establishment and irrigation methods on nitrogen, phosphorus and potassium uptake $(\mathrm{kg} / \mathrm{ha})$ of $\mathrm{B}$. N. hybrid grass

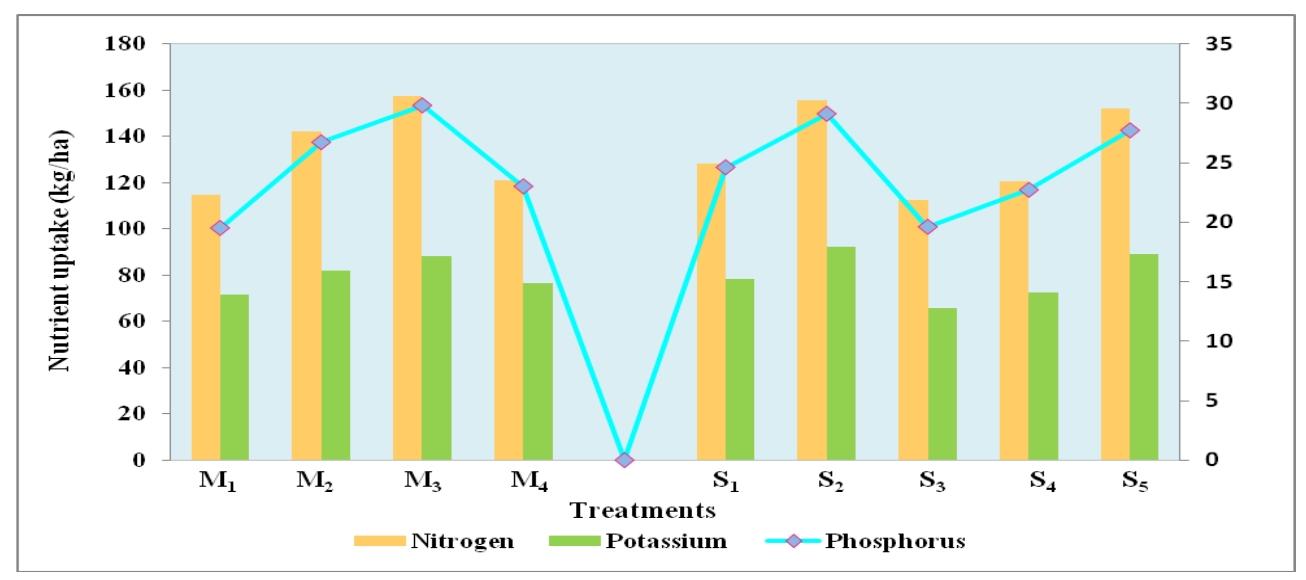

Among the crop establishment methods, vertical planting of setts without sett treatment $\left(\mathrm{S}_{3}\right)$ registered higher soil available potassium of $604.8 \mathrm{~kg} / \mathrm{ha}$. It was at par with horizontal planting of setts without sett treatment $\left(\mathrm{S}_{4}\right)$ which recorded $576.4 \mathrm{~kg} / \mathrm{ha}$ of 
soil available potassium. Soil available potassium of $484.2 \mathrm{~kg} / \mathrm{ha}$ was found to lower under adaption of horizontal planting of setts with sett treatment $\left(S_{2}\right)$. It was followed by vertical planting of two budded setts $\left(\mathrm{S}_{5}\right)$ which recorded $523.7 \mathrm{~kg} / \mathrm{ha}$ of soil available potassium.

\section{Nutrient uptake}

The present study showed significant difference in crop establishment and irrigation method for nutrient uptake (Fig. 1). In crop establishment methods, horizontal planting with sett treatment $\left(\mathrm{S}_{2}\right)$ recorded higher uptake of NPK. This might be due to earlier established root system and increased root mass by sett treatment helped to remove more nutrients from soil. This might also be due to the fact that the horizontal planting had higher number of tiller production and improved tussock perimeter with reduced weed density which in turn improved uptake the nutrient. This is in line with the findings of Ajouri et al., (2004) and Manjunatha et al., (2017). This superiority could also be attributed due to rapid sprouting and establishment, the best survival, high ground green cover and consequently the efficient use of light, soil moisture and nutrients by the plants was reported by Ghassemi-Golezani and Abdurrahmani (2012).

This treatment was on par with vertical planting of two budded setts $\left(S_{5}\right)$. This might be due to higher sprouting and establishment resulting in early vigorous root growth, dense root hairs, combined with early root distribution which would have captured higher amount of nutrients from soil. These results are in conformity with the findings of Akhtar et al., (2000). Alagudurai (2014) also reported that planting of two budded setts sprouted earlier which in turn improved photosynthetic activity thus increased the nutrient uptake on bajra napier hybrid grass.
Significantly lower uptake of NPK was observed with vertical planting of setts without sett treatment $\left(S_{3}\right)$. This might be because of delay in sprouting due to reduction in cell division and elongation which produced lower root mass resulting in lesser growth and dry fodder yield which in turn reflected in lower nutrient uptake. This is in line with the findings of Manjunatha et al., (2017) who stated that vertical planting take longer time for establishment, therefore, the absorption of water and nutrients were delayed which in turn resulted in less quantity of NPK absorption in sugarcane.

Different irrigation methods showed significant difference on nutrient uptake. Higher uptake of NPK was registered with subsurface drip irrigation $\left(\mathrm{M}_{3}\right)$. This was mainly due to timely availability of soil moisture under subsurface drip irrigation resulting in enhanced dry matter production, which ultimately led to increased nutrient uptake (Singh et al., 1997). Further, Sathya et $a l$. , (2008) also expressed that the availability of NPK was higher in root zone area of subsurface drip irrigation which contributed for increased uptake of nutrients. Mary et al., (2016) stated that higher available soil moisture was supplied by subsurface drip irrigation led to higher availability of nutrients in soil which in turn increased the nutrient uptake by the crop. Further, the high nutrient uptake might also be due to the reduced loss of nutrients in subsurface drip compared to other irrigation methods.

This was followed by surface drip irrigation $\left(\mathrm{M}_{2}\right)$ which might be due to better availability of nutrients in root zone as a result of frequent application of water coupled with better root activity thus increased the nutrient uptake. This finding is further supported by Alagudurai (2014) by stating that surface drip irrigation registered higher nutrient uptake compared to surface irrigation, because of 
reduced loss of nutrients in drip irrigation compared to soil application of fertilizer in surface irrigation.

The surface irrigation $\left(\mathrm{M}_{1}\right)$ recorded significantly lower nutrient uptake. This was due to the application of higher amount of water initially might have favoured leaching of nutrients from the soil thereby resulted in lower nutrient uptake. This corroborates with the findings of Haneef et al., (2014) and Sharma et al., (2015) who reported decreased uptake of NPK with lower soil moisture levels. Similarly, Vennila and Ananthi (2019) opined that the occurrence of low soil moisture content between two subsequent high interval irrigations favoured poor nutrient absorption by the plants.

The results from the present investigation on interaction effect revealed that, both the crop establishment and irrigation methods showed non-significant difference on nutrient uptake. This is further confirmed by the findings of Arun et al., (2017).

\section{Post harvest soil available nutrients}

In the present investigation, among crop establishment methods vertical planting of setts without sett treatment $\left(\mathrm{S}_{3}\right)$ registered higher post harvest soil available N, P and $\mathrm{K}$. This might be due to reduced crop uptake in the presence of lower plant population and poor growth parameters in this treatment. Whereas, horizontal planting with sett treatment $\left(S_{2}\right)$ recorded lower post harvest soil available $\mathrm{N}, \mathrm{P}$ and $\mathrm{K}$ which might be due to higher crop uptake resulted by higher growth characters.

Different irrigation methods showed significant difference on post harvest soil available N, P and K. Significantly lower post harvest soil available $\mathrm{N}, \mathrm{P}$ and $\mathrm{K}$ was recorded with subsurface drip irrigation $\left(\mathrm{M}_{3}\right)$.
This result is in accordance with the findings of Mahesh (2015) who reported that subsurface drip irrigation on sugarcane registered lower post harvest available nutrients. This might be due to better utilization and higher uptake by nutrient application at the root zone reduces the losses which led to lower post harvest available nutrients.

Surface irrigation registered higher post harvest soil available $\mathrm{N}, \mathrm{P}$ and $\mathrm{K}$. This might be due to less uptake by poor growth parameters led to higher available nutrients in the soil. This was supported by Archana (2017) who reported that surface irrigation on turmeric and onion resulted in higher post harvest available nutrients.

Interaction effect between crop establishment and irrigation methods showed nonsignificant difference on post harvest soil available N, P and $\mathrm{K}$. This is results was supported by findings of Arun et al., (2017).

From the study it can be concluded that, irrigation methods and crop establishment methods had direct impact on nutrient uptake and post harvest soil available nutrients of bajra napier hybrid grass. From the results it is clearly evident that subsurface drip irrigation and horizontal planting of setts with sett treatment is recommended for achieving better nutrient uptake on bajra napier hybrid grass.

\section{References}

Ajouri, A., H. Asgedom and Becker M. 2004. Seed priming enhances germination and seedling growth of barley under conditions of $\mathrm{P}$ and $\mathrm{Zn}$ deficiency. Journal of Plant Nutrition and Soil Science. 167(5): 630-636.

Akhtar, M., K. Bashir, M.E. Akhtar, M.Z. Khan and Rafiq S. 2000. Effect of 
timing of nitrogen application on agronomic characters and nutrient contents of sugarcane (Sacharum officinarum, L.). Pakistan Journal of Biological Sciences. 3 (4):672-673.

Alagudurai, S., 2014. Effect of crop geometry drip irrigation regimes and nitrogen fertigation on the productivity of bajra napier hybrid grass. Ph.D. (Agri.,) Thesis, Tamil Nadu Agricultural University, Coimbatore.

Archana, H.A. 2017. Performance evaluation of drip and micro sprinkler fertigation in turmeric + onion intercropping system. Ph. D. (Agri.) Thesis, Tamil Nadu Agricultural University, Coimbatore.

Arun, M.N., S.S. Hebbar, K. Bhanuprakas and Senthivel T. 2017. Seed priming improves irrigation water use efficiency, yield and yield components of summer cowpea under limited water conditions. Legume ResearchAn International Journal. 40 (5):864871.

Bhoi, P.G., and More, S.M. 2005. Agronomic aspects for micro irrigation in sugarcane. In Proceedings of National Seminar on Relevance of Micro Irrigation in Sugarcane. Vasantdada Sugar Institute, Pune, Maharashtra, India:77-90.

Ghassemi-Golezani, K., and Abdurrahmani, B. 2012. Seed priming, a way for improving grain yield and nutritional value of barley (Hordeum vulgare, L.) under dry land condition. Research Crops. 13:62-66.

Gomez, K.A., and Gomez, A. A. 1984. Analysis of data from a series of experiments. Statistical Procedures for Agricultural Research. $2^{\text {nd }}$ ed. New York: J. Wiley:316-356.

Haneef, M., R.A. Kaushik, D.K. Sarolia, A. Mordia and Dhakar, M. 2014. Irrigation scheduling and fertigation in pomegranate $\mathrm{cv}$. Bhagawa under high density planting system. Indian Journal of Horticulture. 71 (1):45-48.

Hans, V., 2016. Water management in agriculture: Issues and strategies in India. doi.org/10.2139/ssrn.3072421.

Humphries, E.C., 1956. Mineral components and ash analysis. Modern methods of plant analysis. Springer Berlin Heidelberg 1:468-502.

Jackson, M.L., 1973. Soil Chemical Analysis. Prentice hall of India Private Limited, New Delhi: Pp. 67-214.

Jain, R., S. Solomon, A.K. Shrivastava and A. Chandra. 2010. Sugarcane bud chips: A promising seed material. Sugar Tech. 12 (1):67-69.

Kirnak, H., 2006. Effects of irrigation water salinity on yield and evapotranspiration of drip irrigated cucumber in a semiarid environment. In: Biosaline Agriculture and Salinity Tolerance in Plants. Publishers, Birkhäuser Basel: Pp. 155-162.

Mahesh. R., 2015. Effect of water soluble fertilizer and normal fertilizers on yield and quality of sugarcane under subsurface drip fertigation. Ph. D (Agri.,), Thesis, Tamil Nadu Agricultural University, Coimbatore.

Manjunatha, B., Y.M. Ramesha and Yogeeshappa H. 2017. Nutrient uptake and millable cane yield of sugarcane as influenced by application of slow releasing nitrogen fertilizers. International Journal of Current Microbiology and Applied Sciences. 6 (10):855-862.

Mary, P., P. Jeyaseelan and Anitha R. 2016. Best suited fertigation schedule and its effect on growth, yield, quality and uptake of nutrients of sugarcane (Saccharum officinarum, L.) under Sustainable Sugarcane Initiative method. Research on Crops. 17 (3):616-621. 
Sathya, S., G.J. Pitchai, R. Indirani and Kannathasan M. 2008. Effect of fertigation on availability of nutrients $(\mathrm{N}, \mathrm{P}$ and $\mathrm{K})$ in soil- $\mathrm{A}$ review. Agricultural Reviews. 29 (3):214 219.

Sharma, R., S.K Pandey, and Sharma T.A. 2015. Influence of soil moisture on growth and nutrient content in healthy and malformed panicles of mango varieties. Indian Journal of Horticulture. 72 (1):133-138.

Singh S.N., D.Y. Yadav, T. Singh and Singh G.K. 2011. Optimizing plant population density for enhancing yield of ratoon sugarcane (Saccharum spp.) in sub-tropical climatic conditions. Indian Journal of Agricultural Science. 81 (6):571-574.

Singh, A.K., G.R. Singh and Dixit R.S. 1997. Influence of plant population and moisture regimes on nutrient uptake and quality of winter maize (Zea mays, L.). Indian Journal of Agronomy. 42 (1):107-111.

Vennila, C., and Ananthi T. 2019. Impact of irrigation and nutrients on the performance of bajra napier hybrid grass grown under light sandy soil. International Journal of Current Microbiology and Applied Sciences. 8 (6):804-812.

Vijay, D., C.K. Gupta and Malaviya D.R. 2018. Innovative technologies for quality seed production and vegetative multiplication in forage grasses. Current Science. 114 (1):148.

Waseem M., I. Kaleel, Mallikarjuna and Polisgowsar B.S. 2018. Effect of micro sprinkler and surface irrigation on growth and yield of groundnut crop under raichur agro climatic conditions. Journal of Pharmacognosy and Phytochemistry. 7(1):132-134.

\section{How to cite this article:}

Varshini, S. V. and Jayanthi, C. 2020. Influence of Crop Establishment and Irrigation Methods on Nutrient Uptake and Post Harvest Available Nutrients of Bajra Napier Hybrid Grass CO (BN) 5. Int.J.Curr.Microbiol.App.Sci. 9(12): 1410-1420.

doi: https://doi.org/10.20546/ijcmas.2020.912.170 